\title{
3.2 INTERANNUAL VARIABILITY OF THE WESTERN NORTH PACIFIC SUMMER MONSOON: DIFFERENCES BETWEEN ENSO AND NON-ENSO YEARS
}

\author{
Chia Chou * \\ Institute of Earth Sciences, Academia Sinica, Taipei, 115, Taiwan, ROC
}

Jien-Yi Tu and Jia-Yuh Yu

Department of Atmospheric Sciences, Chinese Culture University, Taipei, 114, Taiwan, ROC

\section{INTRODUCTION}

The interannual variability of the WNP and EA summer monsoons often links to the El Niño-Southern Oscillation (ENSO) (e.g. Chang et al. 2000a, 2000b; Chen et al. 1992; Huang and Sun 1992; Lau and Bua 1998; Lau et al. 2000; Lau and Wu 2001; Nitta 1987; Wang et al. 2001; Weng et al. 1999; Wu and Wang 2000). A weak (strong) WNP summer monsoon and a strong (weak) EA summer monsoon are often preceded by El Niño (La Niña) in the previous winter (e.g. Wang et al. 2001). The WNP and EA summer monsoons also exhibit significant interannual variability in those without ENSO in the preceding winter. This interannual variability might be a part of the tropospheric biennial oscillation or an independent event. For instance, an extremely cold and wet summer associated with a strong EA summer monsoon and a warm and dry summer associated with a weak EA summer monsoon are found in 1993 and 1994 respectively (Geng et al. 2000; Park and Schubert 1997). Thus, it is important to isolate the structure and effects of the WNP summer monsoon by identifying the years other than the mature phases of ENSO, and compare the atmospheric and sea-surface anomalies between the ENSO and non-ENSO years. This study focuses on understanding the spatial and temporal patterns of the interannual variability of the WNP summer monsoon with and without the ENSO influence.

\section{DATA AND A MONSOON INDEX FOR THE WESTERN NORTH PACIFIC SUM- MER MONSOON}

The monthly air temperature, surface pressure and winds used in the study are derived from the 50year (1951-2000) National Centers for Environmental Prediction (NCEP) reanalysis (Kalnay et al. 1996) with a resolution of $2.5^{0} \times 2.5^{0}$. Monthly SST data is from the NCEP using the empirical orthogonal function (EOF) reconstructed SST analysis of Smith et al. (1996) with a resolution of $2^{0} \times 2^{0}$. Monthly precipitation data are from January 1979 to December 2000 derived by the Climate Prediction Center (CPC) Merged Analysis of Precipitation (CMAP)(Xie and

\footnotetext{
* Corresponding author address: Chia Chou, Earth Sciences, Academia Sinica, Taipei, 115, Taiwan, ROC; e-mail <chia@earth.sinica.edu.tw>
}

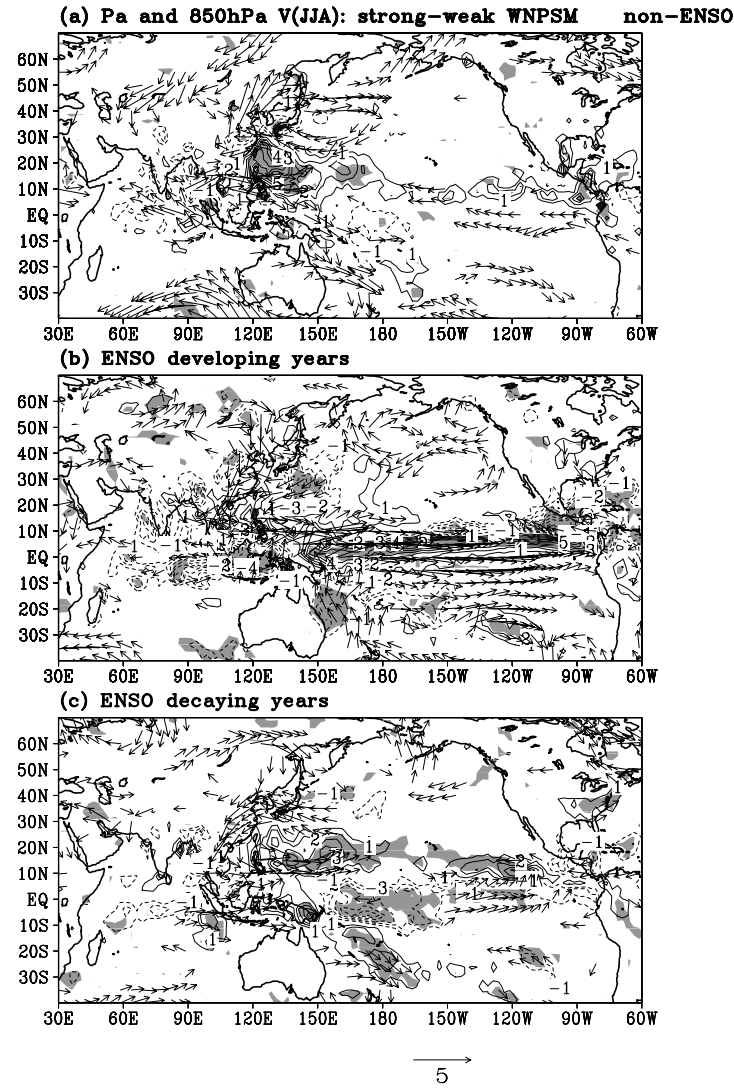

Figure 1. Composite difference of the summer rainfall anomalies and $850 \mathrm{hPa}$ wind anomalies $\left(\mathrm{ms}^{-1}\right)$ between the strong and weak WNP summer monsoons for (a) the non-ENSO years, (b) the ENSO developing years, and (c) the ENSO decaying years. The contour interval is $1 \mathrm{~mm} \mathrm{day}{ }^{-1}$. Areas with significance level at $5 \%$ by two-sample $t$ test are shaded.

Arkin 1997) with a resolution of $2.5^{0} \times 2.5^{0}$. A dynamical monsoon index defined by Wang et al (2001) is used to measure the variability of the WNP monsoon. The WNP monsoon index similar to Wang and Fan (1999) is defined as the difference of $850 \mathrm{hPa}$ westerly anomalies between the region $\left(5^{0}-15^{0} \mathrm{~N}, 100^{0}\right.$ $\left.130^{\circ} \mathrm{E}\right)$ and the region $\left(20^{0}-30^{0} \mathrm{~N}, 110^{0}-140^{\circ} \mathrm{E}\right)$. The WNP monsoon with a positive WNP monsoon index averaged over summer is defined as a strong summer monsoon, and vice versa for a weak WNP summer monsoon with a negative WNP monsoon index over the same period. To determine an ENSO event, we focus on the relation of the WNP summer monsoon with a typical ENSO event that has the phase-locking 
behavior with the mature phase in winter. The Niño$3.4\left(5^{0} \mathrm{~S}-5^{0} \mathrm{~S}, 170^{0} \mathrm{~W}-120^{\circ} \mathrm{W}\right) \mathrm{SST}$ anomalies are used as an ENSO index. A mature phase of the warm event of ENSO (El Niño) is defined when the ENSO index averaged over winter is larger than $0.9^{\circ} \mathrm{C}$ and a mature phase of the cold event of ENSO (La Niña) is defined when the ENSO index averaged over the same period is less than $-0.9^{0} \mathrm{C}$. An ENSO developing year (Year 0 ) is defined as the year before the mature phase of ENSO and an ENSO decaying year (Year 1) is defined as the year after the mature phase of ENSO.

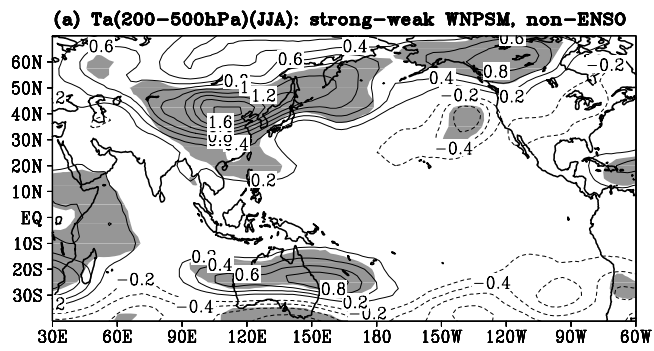

(b) ENSO developing years

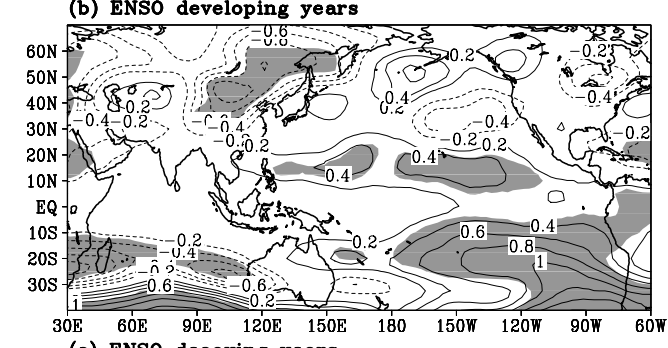

(c) ENSO decaying years

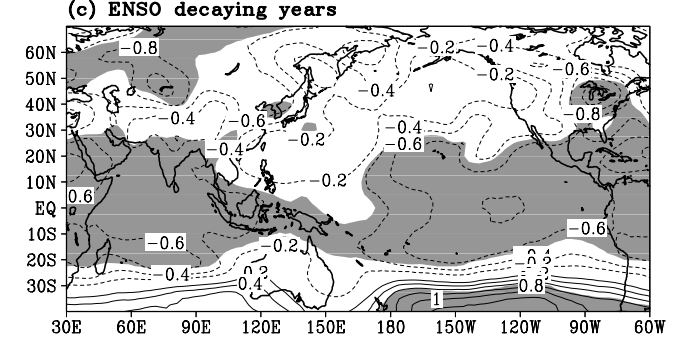

Figure 2. As in Fig. 1, except for the summer upper tropospheric (200-500 hPa) temperature anomalies. The contour interval is $0.2^{0} \mathrm{C}$. Areas with significance level at $5 \%$ are shaded.

3. SPATIAL AND TEMPORAL STRUCTURES OF THE INTERANNUAL VARIABILITY OF THE WESTERN NORTH PACIFIC SUMMER MONSOON

Figure 1 shows the composite differences of summer rainfall between strong and weak WNP summer monsoons in the non-ENSO years (Fig. 1a), the ENSO developing years (Fig. 1b) and the ENSO decaying years (Fig. 1c). According to Fig. 1a, which is the case without any ENSO influence, the positive rainfall anomalies over the region of $5^{0}-25^{0} \mathrm{~N}$ and $110^{0}-180^{\circ} \mathrm{E}$ correspond to the strong WNP summer monsoon defined by $850 \mathrm{hPa}$ zonal winds. The rainfall anomalies associated with the anomalous WNP summer monsoon in Fig. 1a are slightly modified during the
ENSO developing and decaying years. No statistically significant positive rainfall anomalies are found over the subtropical WNP in the ENSO developing year, but the rainfall anomalies over this region do show a positive tendency. The positive rainfall anomalies associated with the horseshoe pattern of the La Niña rainfall anomalies (Wallace et al. 1998) are located over the subtropical WNP in the ENSO decaying year.
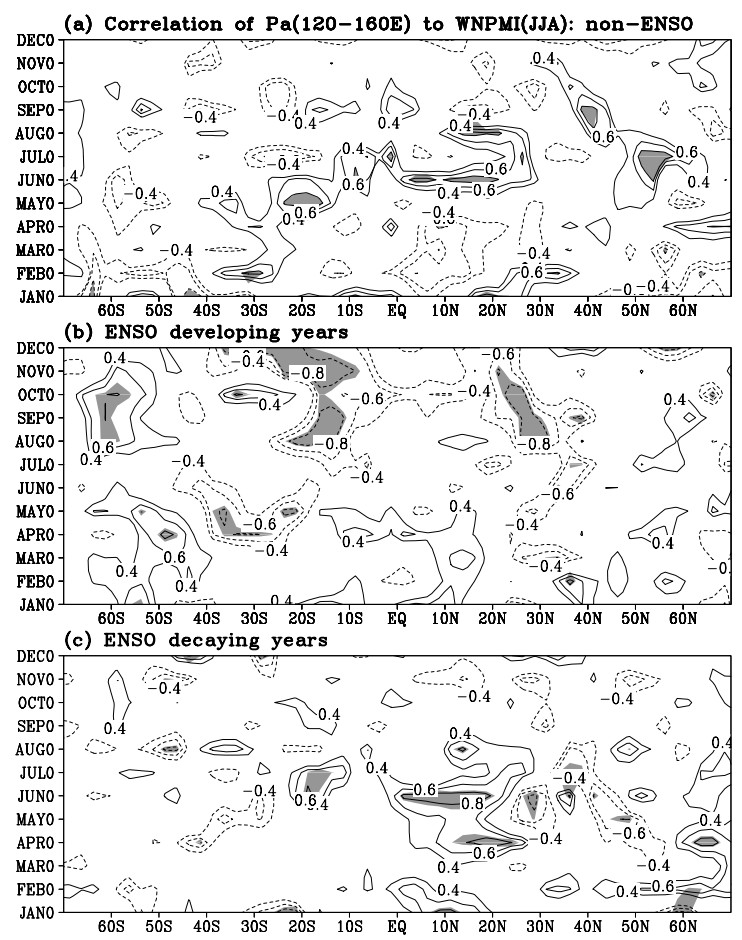

Figure 3. Lag correlation of the monthly rainfall anomalies averaged over $120^{\circ}-160^{\circ} \mathrm{E}$ with respect to the summer WNP monsoon index (Wang et al. 2001) for (a) the non-ENSO years, (b) the ENSO developing years, and (c) the ENSO decaying years. The contour interval is 0.2 . Areas with significance level for the Pearson's $t$-test at $5 \%$ are shaded.

In Fig. 1, a cyclonic circulation at $850 \mathrm{hPa}$ associated with the strong WNP summer monsoon are found in all of the non-ENSO, ENSO developing and ENSO decaying years. This implies the weakening of the WNP subtropical ridge which is associated with a weak EA summer monsoon (Chang et al 2000a). Beginning with the cyclonic circulation anomalies in the subtropical WNP, a wave train of the $850 \mathrm{hPa}$ wind anomalies along the east coast of Asia is found in all three categories with a slight difference and extends to North America. Besides the cyclonic circulation anomalies in the subtropical WNP, the wave train includes the anticyclonic circulation anomalies over Korea and Japan, the cyclonic circulation anomalies from northeastern Asia to the Bering Sea, and the anticyclonic circulation anomalies over the Gulf of Alaska and northern North America. The southern branch of the subtropical WNP cyclonic circulation merges with the anomalous westerlies over the equa- 
torial Pacific which respond to the warm Niño-3.4 SST anomalies. It provide the evidences of the association between the WNP summer monsoon and El Niño.

Figure 2 shows the upper tropospheric temperature anomalies averaged over 200-500 hPa. In the nonENSO year, strong upper tropospheric warming is found over the Asian continent between $25^{0}-50^{0} \mathrm{~N}$. The enhanced meridional gradient of the upper tropospheric temperature over Asia favors a strong WNP summer monsoon (Chou 2002; Li and Yanai 1996). In the ENSO developing year, the cold upper tropospheric temperature anomalies dominate the eastern part of Asia during the strong WNP summer monsoon, so the meridional upper tropospheric temperature gradient is weakened and disfavors a strong WNP summer monsoon. Thus, the meridional upper tropospheric temperature gradient is no longer a forcing for the anomalous WNP summer monsoon in the ENSO developing year. In the ENSO decaying year, the upper troposphere in the tropics is dominated by the typical La Niña-induced cold temperature anomalies, as described by Wallace et al. (1998), during the strong WNP summer monsoon. The meridional upper tropospheric temperature gradient averaged over Asia varies little (not shown), so the meridional upper tropospheric temperature gradient is also not a forcing for the anomalous WNP summer monsoon in the ENSO decaying year.

To study the temporal variation of the anomalous WNP monsoon, the variables associated with the anomalous WNP monsoon are averaging over $120^{\circ}$. $160^{\circ} \mathrm{E}$, a region dominated by the WNP monsoon, and correlate with the summer WNP monsoon index. Bearing in mind the caveat that not all anomalies occur exactly between $120^{\circ} \mathrm{E}$ and $160^{\circ} \mathrm{E}$, the averaged anomalies over $120^{\circ}-160^{\circ} \mathrm{E}$ might not be statistically significant to identify the temporal variations of the anomalies. Nevertheless, the tendency of the temporal variations of the features associated with the anomalous WNP monsoon found in Figs. 3 and 4 is the good indication based on the sensitivity tests with varied regions for the different fields and categories (not shown). Figure 3 shows the lag correlation of the monthly rainfall anomalies to the summer WNP monsoon index. In the non-ENSO year, the positive rainfall anomalies associated with the strong WNP summer monsoon (Fig. 1a) persist for three months (JJA). No statistically significant signal is found during northern summer in the ENSO developing year, as expected according to Fig. 1b. Two negative rainfall anomalies associated with the negative correlation (Fig. 3b) at $20^{\circ}$ on both sides of the equator from $\mathrm{Au}-$ gust to December correspond to a horseshoe pattern of the rainfall anomalies of a typical El Niño ( $\mathrm{Su}$ et al. 2001; Wallace et al. 1998). In the ENSO decaying year, the positive rainfall anomalies associated with the strong WNP summer monsoon exist not only in summer, but they tend to persist from the previous winter when La Niña is mature. This is consistent with the finding of Wang et al. (2000). In contrast to the rainfall anomalies of the WNP monsoon, the corresponding EA monsoon rainfall anomalies do not have a statistically significant signal in the non-ENSO, ENSO developing and ENSO decaying years. It might be due to the smaller region of the corresponding EA monsoon rainfall anomalies.

Figure 4 shows the lag correlation of the surface pressure anomalies averaged over $120^{\circ}-160^{\circ} \mathrm{E}$ to the summer WNP monsoon index. During the strong WNP summer monsoon, the corresponding low surface pressure anomalies between $10^{0}-20^{\circ} \mathrm{N}$ in the nonENSO and ENSO developing years can only exist in summer (Figs. 4a and 4b). In the ENSO decaying year, the corresponding low surface pressure anomalies persist from the previous winter when La Niña is mature. In the mature phase of La Niña, the western Pacific is dominated by the low surface pressure anomalies (Wallace et al. 1998). When La Niña is decaying, the region dominated by the low surface pressure anomalies becomes more meridionally confined to the subtropical WNP. The persistence of the surface pressure anomalies is an evidence that ENSO may affect the WNP summer monsoon in the following summer.
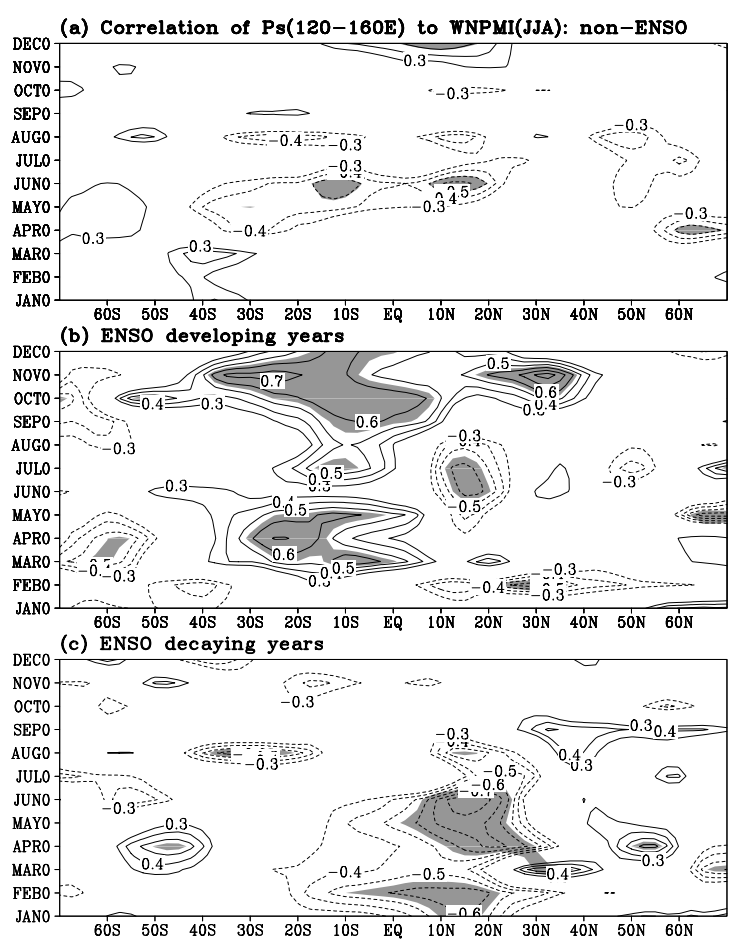

Figure 4. As in Fig. 3, except for lag correlation of the monthly surface pressure anomalies averaged over $120^{\circ}-160^{\circ} \mathrm{E}$ with respect to the summer WNP monsoon index. The contour interval is 0.1 . Areas with significance level at $5 \%$ are shaded.

\section{DISCUSSION}

A strong (weak) WNP summer monsoon tends to occur in the El Niño (La Niña) developing year and 
the La Niña (El Niño) decaying year. The analysis suggests that the anomalous WNP summer monsoon is related to different processes for the non-ENSO, ENSO developing and ENSO decaying years. In the non-ENSO year, the variation of the meridional upper tropospheric temperature gradient might be responsible for the anomalous WNP summer monsoon. In the ENSO developing year, processes related to the eastward extension of the eastern Pacific SST anomalies associated with ENSO could be the reason for the anomalous WNP summer monsoon. In the ENSO decaying year, the western Pacific SST anomalies in the mature phase of ENSO might associate with the anomalous WNP summer monsoon. These processes involving the interannual variability of the WNP summer monsoon in the non-ENSO, ENSO developing and ENSO decaying years are currently under investigation.

Acknowledgments. This work was supported under National Science Council grant 90-2119-M-001020 and the Environmental Change Research Project of Academia Sinica.

\section{REFERENCES}

Chang, C.-P., Y. Zhang, and T. Li, 2000a: Interannual and interdecadal variations of the East Asian summer monsoon and tropical Pacific SSTs. Part I: Roles of the subtropical ridge. J. Clim., 13, 4310 4325 .

Chang, C.-P., Y. Zhang, and T. Li, 2000b: Interannual and interdecadal variations of the East Asian summer monsoon and tropical Pacific SSTs. Part II: Meridional structure of the monsoon. J. Clim., 13, 4326-4340.

Chen, L., M. Dong, and Y. Shao, 1992: The characteristics of interannual variations on the East Asian monsoon. J. Meteorol. Soc. Jpn, 70, 397421.

Chou, C., 2002: Land-sea heating contrast in an idealized Asian summer monsoon. Revised for Clim. Dyn., .

Geng, Q. Z., A. Sumi, and A. Numaguti, 2000: Role of transients in the dynamics of east Asian summer seasonal mean circulation anomalies - A study of 1993 and 1994. J. Clim., 13, 3511-3531.

Huang, R., and F. Sun, 1992: Impacts of the tropical western Pacific on the East Asian summer monsoon. J. Meteorol. Soc. Jpn, 70, 243-256.

Lau, K.-M., and W. Bua, 1998: Mechanism of monsoon-Southern Oscillation coupling: Insights from GCM experiments. Clim. Dyn., 14, 759-779.

Lau, K.-M., K.-M. Kim, and S. Yang, 2000: Dynamical and boundary forcing characteristics of regional components of the Asian summer monsoon. J. Clim., 13, 2461-2482.
Lau, K.-M., and H. T. Wu, 2001: Principal modes of rainfall-SST variability of the Asian summer monsoon: A reassessment of the monsoon-ENSO relationship. J. Clim., 14, 2880-2895.

Li, C., and M. Yanai, 1996: The onset and interannual variability of the Asian summer monsoon in relation to land-sea thermal contrast. J. Clim., 9, $358-375$.

Nitta, T., 1987: Convective activities in the tropical western Pacific and their impacts on the Northern Hemisphere summer circulation. J. Meteorol. Soc. Jpn, 65, 165-171.

Park, C.-K., and S. D. Schubert, 1997: On the nature of the 1994 East Asian summer drought. J. Clim., 10, 1056-1070.

Smith, T. M., R. W. Renolds, R. E. Livezey, and D. C. Stokes, 1996: Reconstruction of historical sea surface temperatures using empirical orthogonal functions. J. Clim., 9, 1403-1420.

Su, H., J. D. Neelin, and C. Chou, 2001: Tropical teleconnection and local response to SST anomalies during the 1997-1998 El Niño. J. Geophys. Res., 106, 20025-20043.

Wallace, J. M., E. M. Rasmusson, T. P. Mitchell, V. E. Kousky, E. S. Sarachik, and H. von Storch, 1998: On the structure and evolution of ENSO-related climate variability in the tropical Pacific: Lessons from TOGA. J. Geophys. Res., 103, 14241-14260.

Wang, B., and Z. Fan, 1999: Choice of South Asian summer monsoon indices. Bull. Am. Meteorol. Sci., 80, 629-638.

Wang, B., R. Wu, and X. Fu, 2000: Pacific-East Asian teleconnection: How does ENSO affect East Asian climate? J. Clim., 13, 1517-1536.

Wang, B., R. Wu, and K.-M. Lau, 2001: Interannual variability of the Asian summer monsoon: Contrasts between the Indian and the western North Pacific-East Asian monsoons. J. Clim., 14, 40734090.

Weng, H., K.-M. Lau, and K.-K. Xue, 1999: Multiscale summer rainfall variability over China and its long-term link to global sea surface temperature variability. J. Meteorol. Soc. Jpn, 77, 845-857.

Wu, R., and B. Wang, 2000: Interannual variability of summer monsoon onset over the western North Pacific and the underlying processes. J. Clim., 13, 2483-2501.

Xie, P., and P. A. Arkin, 1997: Global precipitation: A 17-year monthly analysis based on gauge observations, satellite estimates, and numerical outputs. Bull. Am. Meteorol. Sci., 78, 2539-2558. 